\title{
The Significance of Vision and Mission Development for Enterprises in Slovak Republic
}

\author{
Z. Papulova
}

\begin{abstract}
Vision and mission are often considered as an essential part of strategic management. There is probably not a strategic management book that does not mention or explain the importance of these two elements. In history we can find beautiful examples of great visions of e.g. Bill Gates, Steve Jobs or Henry Ford that stay behind companies' success. Based on these examples we often try to analyze how successful vision and mission statements should be created and defined. But there are still some people that remain skeptical on this subject. They see these statements only as formal documents or just another "marketing tool," not a strategic one. There is also often confusion also with distinguishing vision and mission. The goal of this paper is to investigate the role, the attitude and significance of vision and mission statements for enterprises in current environment. It will discuss the experiences and approaches to vision and mission development in the Slovak Republic based on research from 2012. The research was based on gathering of information by questionnaires and structured interviews in companies operating in Slovak Republic from various sectors and on quantitative analysis.
\end{abstract}

Index Terms-Mission, mission statement, vision, vision statement, enterprises in Slovak Republic.

\section{INTRODUCTION}

Some enterprises do not have vision or mission statements; for some they mean the same or they are quite unclear in how both statements may be defined. If we study the various companies in terms of their vision and mission, we will find a lot of different approaches and styles. Similarly, there are varying theoretical views on vision and mission development.

Vision and mission are not new terms or topics of research. Even in ancient Greece, there were two views on how to develop a vision. The first view explained visions as emerging pictures based on visual rays emanating from the eye [1]. This view was promoted by the mathematician Euclid (300 BC). The second view explained visions as images generated in our mind based on knowledge and experiences. This was the view of Aristotle (384-322 BC) and Plato (427-347 BC). Plato claimed in his dialogues that our thoughts are guided by our desires mainly derived from our experiences.

Many experts in this field admit that there is not one precise or ideal way to develop mission and vision in the organization. But the issue is not only about the creation and development but also about seeking the value, meaning and significance of vision and mission for management of

Manuscript received March 24, 2013; revised May 29, 2013.

Z. Papulova is with the University in Bratislava, Faculty of Management (e-mail: zuzana.papulova@fm.uniba.sk). organizations and about their implementation in praxis.

As the environment is constantly changing, the theory of strategic management is developing as well.

The importance of vision and mission is not declining and is still a real and interesting area to research.

\section{POSITION OF Vision AND MisSiOn In StRATEGIC MANAGEMENT}

The development of vision and mission is a part of the strategic management process. The process of strategic management is often described as a model that involves four basic elements: environmental scanning, strategy formulation, strategy implementation and evaluation and control [2]. The development of vision and mission is a part of strategy formulation. This step not only includes the vision and mission development but also specification of strategic objectives and strategy development.

The relationship between strategy, strategic goals and vision is marked on the Fig. 1 [3].

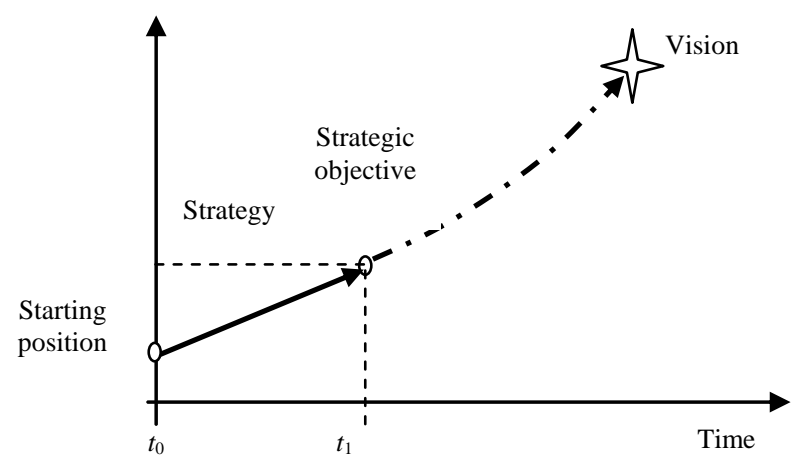

Fig. 1. Strategy, strategic objective and vision.

If the task of the strategy is to lead us to the desired strategic position, defined as the strategic goal of our direction at a certain time, the vision and the mission should tell us more about the future and our future direction. Vision and mission should explain why we chose the specific strategy. Strategic objective, unlike vision, is generally perceived as an obligation rather than an image or prediction. Strategic objectives promote the intentions, speak about what positions we take, and eventually the results that we would like to achieve.

A constantly changing and unpredictable environment does not create favorable conditions for the development of long-term plans and strategies. Nevertheless, it is necessary to have something besides strategy that will provide long-term orientation and direction for us. 


\section{DEVELOPMENT OF VISION AND VISION STATEMENT}

\section{A. Vision in Strategic Management}

Vision is generally seen as a picture of the future. It is a picture of excellence, something that the person, team or organization wants to create in its best possible future.

Vision guides and perpetuates corporate existence. Vision is viewed as a mental picture of a compelling future situation. It originates from creative imagination, the act or power of perceiving imaginative mental images, sort of foresightedness. [4]

Visionaries are those who can create compelling images of the future. Vision in terms of strategy cannot be an ordinary picture of the future that can be created by anyone who knows the past and the present. Vision is a picture of the future that is based on ideas outrunning present time and that often motivates generations of managers.

Vision in this understanding should be developed based on ideas about future dominant factors and their impacts that will create an environment different from the environment in the past or present. Vision is particularly important to reveal new factors and new connections in the environment. There are many examples of such visions. At least we can recall the vision of IBM founder - Thomas Watson. It has been almost hundred years since the founder came up with a vision to establish a sector of informatics and information technologies that previously did not exist. Thanks to this vision, IBM became one of the most successful companies in this area and still retains a significant position on the market till this day.

Vision is an essential ingredient in the success of any company. It provides the driving force that can get a company through the growing pains it will inevitably encounter. It is a basic "shape" of the company future; it expresses optimism, and hope about possibilities regarding the desired future. [5]

\section{B. Development of Vision}

There are several ways to develop a vision [3]:

- to discover visions through intuition,

- to use a team approach to develop a vision,

- to use a rational approach,

- to adapt the vision of other subjects.

Using intuition is the traditional way to discover and develop a vision. Vision is seen as an idea which surprisingly and suddenly approached its creator - a visionary. It rarely occurs intentionally. Often these visionaries are also founders of organizations (like Thomas Watson or Steve Jobs) who can lead the whole organization towards vision achievement.

A team approach is another option for vision development. Working in a team with people that can bring unusual ideas, views and inspirations can be very beneficial and result in creative and innovative solutions. Every individual has abilities and an incredibly large capacity of mind. If we consider that there is team of people who are creative and are thinking strategically, we could apply the saying, "two heads are better than one."

The rational approach to vision development is another possible alternative. This approach uses rational and logical thinking. In this case, we rely on analysis and synthesis, induction and deduction, comparison and other techniques of empirical investigation. But this approach will never lead us to new revolutionary or radical vision because it relies on suggested techniques and practices based on analyzing information from the past. Rational thinking is a conservative approach that will never lead us to creative solutions.

The last possibility is to adapt the vision of another subject/organization. We can be motivated by the vision of another organization and understand its importance and significance. In this is the case we can join this subject and as a partner work together to fulfill the vision.

\section{Vision Statement}

A vision may or may not find its expression in vision statements. The length and complexity of the vision statement differ between organizations. [6] Generally, we can recommend that the vision statement be:

- easy to understand

- easy to remember

- positive

- motivational

- inspiring

- attractive

- challenging

- future-oriented.

The organization and its employees should be identified with the vision statements. Great visions not only need visionaries but also leaders who can communicate the vision to others and get support from partners.

\section{DeVelopment of Mission AND Mission Statement}

\section{A. Mission in Strategic Management}

The mission is an important part of strategic management. It should be defined before we develop the strategy. The mission defines the space in which we create a strategy. Unlike the vision that allows us determine direction and indicates where we want to get to, mission defines the space in which the company will operate. The mission therefore relates to the present and future directions. Mission, unlike vision, is not directed to the distant future. It would be preferable to say that the mission itself has not a built-in time dimension. It is rather timeless in character. Its purpose is to present the subject in its essence, in its permanent and long-term sustainable way of being.

An organization's mission seeks to answer the question as to why an organization exists. [6]

Companies are like people; they need a mission. Without a purpose or a mission, people and companies will flounder. [7] Mission is shaping the identity, purpose and direction of an organization.

It is not only a source of direction for employees, it is also there for customers, stockholders and the public to know about the fundamental principles by which a business operates. It may also explain company values, beliefs, philosophy and aspirations.

\section{B. Development of Mission Statement}

A mission statement can be defined as a way in which the 
organization communicates the business it is in to the outside world. [6]

Development of mission statements is based on several decisions. The main concern should be about the target audience of our mission statement. The target audience of the mission statement can vary following the purpose of the mission statement. Companies need to first clearly identify the target audiences and communication potential of the mission statement.

Multiple audiences can addressed with the statement, like staff, employees, customers, clients, colleagues, partners, stockholders, patrons, community. These decisions will have the significant impact on tone, length, communication and visibility of mission statements. [7]

There is no one way of creating an effective mission statement; there is no recommended format, formula or pattern focusing on reaching the target audience. Experts and researchers in this field however recommend some suitable elements of mission statements.

F. David suggests these nine components in the mission statement [8]:

1) Customers (the target market)

2) Products/Services (offerings and value provided to customers)

3) Geographic Markets (where the firms seeks customers)

4) Technology (the technology used to produce and market products)

5) Concern for Survival/Growth/Profits (the firm's concern for financial soundness)

6) Philosophy (the firm's values, ethics, beliefs)

7) Public Image (contributions the firms makes to communities)

8) Employees (the importance of managers and employees)

9) Distinctive Competence (how the firm is different or better than competitors).

These various aspects of the mission are often neglected. In this way, the company has the opportunity to present its values and added values for different subjects. It is a manifestation of our wisdom and also a sign that we are not here just for ourselves.

\section{APPROACHES OF SLOVAK ENTERPRISES}

\section{A. Research Description}

The approach of Slovak enterprises towards the vision and mission development is evaluated through research(September 2012 - December 2012). The gathering of information was done by questionnaires and structured interviews in companies operating in Slovak Republic from various sectors. A total of 242 enterprises of various sizes were studied and analyzed (Table I).

TABLE I: ENTERPRISES IN RESEARCH (2012)

\begin{tabular}{lll}
\hline \hline Size & Number & $\%$ \\
\hline Micro Enterprises & 63 & $26,03 \%$ \\
Small Enterprises & 77 & $31,82 \%$ \\
Medium Enterprises & 52 & $21,49 \%$ \\
Large Enterprises & 50 & $22,66 \%$ \\
\hline \hline
\end{tabular}

\section{B. Approaches to Vision Development}

The first area of research focused on study and analysis of an actual state and attitudes of enterprises towards vision creation, vision importance and identification with vision.

The result shows that only 24 companies out of 242 (9, $92 \%$ ) did not have a vision in 2012. These companies (without vision) were mostly micro and small enterprises (83, $43 \%$ ) as it could be assumed. Small enterprises are in general less strategically oriented.

11 companies $(4,55 \%)$ even stated that they will not consider creating a vision in the future. The rest of the companies feel the absence of vision.

22 companies (9\%) feel that vision is just a formal document without any strategic purpose. 26 companies (10, $74 \%$ ) understand the importance of vision in strategic terms. But the majority of companies $(69,60 \%)$ consider vision as a basis for their strategy and that strategy is headed towards vision.

The vision of 90 companies $(37,19 \%)$ was created by its founder. Only 4 companies $(1,65 \%)$ used consulting services in order to help create vision. The rest of the companies used team approach to vision creations (35\% strategic groups, $17 \%$ group of managers from various levels and departments).

141 companies $(58,26 \%)$ are satisfied with their vision statements and are able to identify themselves with their vision.

\section{Approaches to Mission Development}

The second area of research focused on the study and analysis of an actual state and attitudes of enterprises towards mission. I analyzed their views on mission, their attitudes to mission and its strategic importance and their approach to mission statement development.

I found out that 54 companies out of 242 companies (22, $31 \%$ ) did not have a mission in 2012. 79, 63\% of these 54 companies (without mission) were small and micro enterprises. If we compare it with results in vision, we can see that twice as many companies do not have a clear mission.

Moreover there are still many companies that do not recognize the difference between vision and mission $(39 \%)$. This lack was common mostly $(93,22 \%)$ among micro, small and medium enterprises. As I mentioned earlier, each of these strategic elements has its own characteristics and purpose. When it is mixed, they risk losing their role and purpose.

A positive approach could be seen in the analysis of the strategic importance of mission. Only 14 companies $(5,79 \%)$ believe that mission does not have any strategic significance and should not be seen as a strategic element. The rest of the companies agreed with the strategic role of the mission. For the majority of companies with defined mission $(77,6 \%)$, this is also applied in praxis. They stated that their mission influences their strategy and it sets the strategic direction and space for strategy and their business.

The last analysis was dedicated to development of mission statements. Almost half of the companies $(46,28 \%)$ have mission statements created by founders. The others prefer to develop mission statements in teams of managers. Only $1 \%$ used consultancy help for mission statement development.

In terms of target audience of mission statement, I found 
out that in most cases companies choose to address the mission statement to only one audience. The target audience are customers in the majority $(70,74 \%)$ of cases.

The rest of the companies use more elements in their mission statement. They usually address the mission statement to customers (the target market), employees and partners. These statements describe products, services, industries or business areas in which the company operates, and they describe also other values and value orientations.

Table II shows which elements were used in the analyzed mission statements from companies.

TABLE II: MisSION STATEMENT ELEMENTS

\begin{tabular}{lll}
\hline \hline Elements & Number & $\%$ \\
\hline Customers & 133 & $70,74 \%$ \\
Products/Services/Industry & 116 & $61,70 \%$ \\
Employees & 80 & $42,55 \%$ \\
Partners & 69 & $36,70 \%$ \\
Founders/Stockholders & 21 & $11,17 \%$ \\
Concern for environment & 65 & $13,30 \%$ \\
Other elements & 44 & $23,40 \%$ \\
\hline \hline
\end{tabular}

To conclude, only two companies $(1,06 \%)$ were close to the approach presented by F. David concerning the nine components of mission statements.

\section{CONCLUSION}

Vision in strategic management has several functions. First of all, it gives direction. It is a reference point in the future, indicating where you are going and why. Vision tells us also about the future and suggests how we should change, where we will get and how we will be in future. Vision acts as motivation, it offers us new possibilities about how we can succeed.

The research in Slovak enterprises showed quite positive attitudes towards vision development. More than $90 \%$ of the companies nowadays have visions and only $4,5 \%$ of companies do not consider creating one.

Almost $70 \%$ of companies recognize the strategic importance and significance of the vision. This positive trend is not only among the large companies, although we can still see small and micro enterprises struggling with strategic management orientation.

The majority of visions $(52 \%)$ were created in teams. Team approach is a current trend in vision development because of its creative potential. But still we can find many visions created $(37 \%)$ by founders of companies.

Companies can choose to express their vision in vision statements. More than half of companies (58\%) were satisfied and identified with its vision statement formation.

The mission should emphasize the main focus of the company and its activities. It usually says what is our main field or activity and in which market do we operate. It should explain the "who we are" and "what we do". Additionally, companies can use the mission broadly. Mission can cover wider dimensions such as a philosophical dimension, in which we refer to "why we exist" and "what is the meaning of our existence."

According to the research, and I might say, surprisingly, more companies did not have mission (22\%) in comparison with vision (10\%). Generally, we can say, that vision is much harder to prepare because of its long term orientation and its message about our future and strategic direction. Vision is also seen as a more stable element. We can prepare visions for years ahead without actualizations. On the other hand, mission can be updated more frequently; it should be always fitted to our business. There are always debates about what we should prepare first, mission or vision and if we need both. In my opinion, both are necessary and they should be determined before the business started to operate and possibly updated if there is some necessary shift in our business.

Many companies (39\%) do not recognize the difference between the vision and mission. There is often confusion if the vision and mission should be viewed and prepared as the same statement. By the nature of the vision and mission, I believe that each of these statements has a different purpose and meaning and should retain its characteristics and be presented in the "right" way.

A positive approach could be seen in the recognition of mission. The majority of companies with formulated mission statements $(77 \%)$ understand the concept and strategic importance and significance of mission.

The approach most often used to develop a mission statement was a singe target audience orientation. We can also see a positive trend in mission statement development; companies not only address their mission statements to customers but also look for other audiences and presentations of their values. Over all, we can say there is still a potential for improvement of mission statements in enterprises in Slovak republic.

\section{REFERENCES}

[1] I. Putri. (2007). Ancient Theories of Vision and Al-Kindi's Critique of Euclid's Theory of Vision. Isis. [Online] pp. 1-9 Available: http://campar.in.tum.de/twiki/pub/Chair/TeachingSs07ScienceHistory / HistoryOfVision1H.pdf

[2] T. L. Wheelen and J. D. Hunger, Strategic Management and Business Policy, 3rd ed., MA: Addison-Wesley Publishing Company, 1989, ch. 1, pp. 10-17.

[3] J. Papula, Z. Papulova, Strategický Manažment. Teoretické Východiská Alebo Jadro Vedomostí, 1st. ed. Bratislava, SR: Kartprint, 2009, ch. 4, pp. 50-51.

[4] A. Joachim, "Interface between Corporate Vision, Mission and Production and Operations Management," GJMBR, vol. 10, no. 2 pp. 18-23, April 2010.

[5] M. Lipton, Guiding Growth: How Vision Keeps Companies on Course, Boston, MA: Harward Business School Press, 2003, ch. 1, pp. 15-18.

[6] A. Henry, Understanding Strategic Management, Oxford, UK: Oxford University Press, 2008, ch. 1, pp. 11-12.

[7] J. Abrahams, Plus Guidelines for Writing Your Own Mission Statement 101 Mission Statements from Top Companies, 1st. ed. Berkeley, CA: Ten Speed Press, 2007, ch. 1, pp. 1-8.

[8] F. David and F. David. (January / February 2003). It's Time to Redraft Your Mission Statement. Journal of Business Strategy. [Online] 24 (1), pp. 11-14. Available: http://www.esf.edu/for/germain/David_8_12.pdf

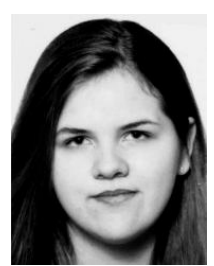

Zuzana Papulova was born in Bratislava, Slovak Republic, $9^{\text {th }}$ of February 1981. Her educational background: Bachelor degree in Management, Faculty of Management, Comenius University in Bratislava, Slovak Republic, 2002, Master's degree in Management, with specialization in Strategic Management, Faculty of Management, Comenius University in Bratislava, Slovak Republic, 2004, PhD. Degree in Business 
management, Faculty of Management, Comenius University in Bratislava, Slovak Republic, 2007

She also studied internationally, one trimester at Faculty of Economics, University of Groningen, Netherlands in 2002. She completed the International Faculty Development Program at IESE Business School, The University of Navarra, Barcelona, Spain, in 2007 and Summer Business Program: Strategic Business Development with Europe in Lyon, France in 2009.

In 2004 she worked as a Business Process Specialist in Slovak Telecom, a. s. From 2007 until now she is as an Academic Lecturer at Faculty of
Management, Comenius University in Bratislava, Slovak Republic. She is an author and co-author of several publications and articles. The most important books: Strategic Analyses with support of Strategic thinking (Bratislava, Slovakia, Kartprint. 2012), Strategy and strategic management (Bratislava, Slovakia Iura Edition, 2012), Strategic thinking of managers (Bratislava, Kartprint, 2010).

Dr. Papulova is a member of various research projects and is an active researcher, lecturer and thesis supervisor, twice rewarded by the Rector of Comenius University in Bratislava. 